\section{JURNAL ABDIMAS

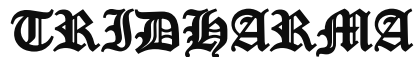 \\ 代A}

\title{
PEMBEKALAN DAN PELATIHAN DESIGN GRAFIS GUNA MENUMBUHKAN JIWA ENTERPREUNERSHIP PADA ANAK USIA DINI DI YAYASAN YATIM PIATU KHAZANAH KEBAJIKAN
}

\author{
Anggada Bayu Seta, Sri Mulyani, Dede Abdurohman, Nurul Ilham, Roni Fadli \\ Dosen Fakultas Ekonomi Bisnis Universitas \\ Pamulang \\ Email dosen02245@unpam.ac.id
}

\begin{abstract}
ABSTRAK
Tujuan dari pelaksanaan program pengabdian masyarakat ini adalah untuk meningkatkan pemahaman dan keterampilan anak asuh dari panti asuhan pada yayasan yatim dan piatu khazanah kebajikan untuk menjadi seorang wirausahawan dalam mengahadapi persaingan di masa depan yang kian ketat dan kompetitif. Metode yang di gunakan di dalam kegiatan pengabdian kepada masyrakat yang di selenggarankan oleh para akademisi dari universtias pamulang ini menggunakan metode resitasi yang didalamnya di jelasakan materi tentang pemahaman akan jiwa enterpreunerships dan kepemimpinan, penerapan ipteks yang dilakukan adalah dalam bentuk pembekalan dan pelatihan pengenalan serta eksplorasi terkati seni desain grafis dengan menggunakan aplikasi coreldraw. Kegiatan pembekalan dan pelatihan keterampilan didalam kegaitan pengabdian kepada masyrakat ini ditunjang dengan sesi tanya jawab dan tentu saja praktek secara langsung yang disertai dengan output produk secara langsung. Modul pelatihan akan diberikan kepada peserta sebagai alat bantu dalam kegiatan praktek. Berdasarkan hasil evaluasi serta temuan-temuan yang diperoleh selama pelaksanaan kegiatan pengabdian kepada masyrakat ini, di peroleh hasil bahwa kegiatan pengabdian kepada masyrakat ini telah mampu memberikan manfaat yang sangat besar dan tepat sasaran bagi khalayak anak-anak panti asuhan yang menjadi khalayak sasaran dalam kegiatan ini. Bentuk pelatihan seperti ini merupakan bentuk yang sangat efektif untuk memberikan penyegaran dan tambahan wawasan serta pengetahuan baru di bidang teknologi informasi di luar proses pembelajaran yang diterima di sekolah masing-masing.
\end{abstract}

\section{Kata Kunci : Desain Grafis, Wirausaha}

\section{ABSTRACT}

The purpose of the implementation of this community service program is to improve the understanding and skills of foster children from orphanages in orphanages and treasures of virtue orphanages to become entrepreneurs in the face of increasingly tight and competitive future competition. The method used in community service activities organized by academics from the University of Pamulang uses the recitation method in which material is explained about understanding the spirit of entrepreneurship and leadership, 


\section{JURNAL ABDIMAS

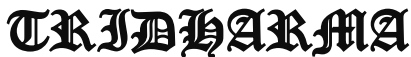

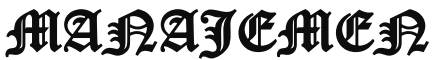

P-ISSN 2615-6849, E-ISSN 2716-070X

Jurnal ABDIMAS Vol.3,No.1,Desember 2021,Hal(92-99)

@ Prodi Manajemen Fakultas Ekonomi Universitas Pamulang

Email: abdimasjurnal.unpam@ gmail.com Telp: (021) 741-2566

the application of science and technology is carried out in the form of debriefing and training related to introduction and exploration. the art of graphic design using the CorelDraw application. The debriefing and skills training activities in community service activities are supported by question and answer sessions and of course direct practice accompanied by direct product output. Training modules will be given to participants as a tool in practical activities. Based on the results of the evaluation and the findings obtained during the implementation of this community service activity, it was found that this community service activity has been able to provide enormous and targeted benefits for the audience of orphanage children who are the target audience in this activity. . This form of training is a very effective form of providing refreshment and additional insight and new knowledge in the field of information technology outside of the learning process received in their respective schools.

\section{Key Words : Grafic Design, Enterpreunership}

\section{PENDAHULUAN}

Generasi muda adalah generasi penerus bangsa, maju atau tidak suatu bangsa amat ditentukan oleh mutu dan kompetensi yang di miliki oleh generasi muda. Istilah golden age selalu disandingkan dengan keberhasilan seseorang di usia muda yang mampu dan berhasil membuat perbedaan dan perubahan serta mampu menginspirasi orang lain, pemahaman tentang golden age ini jika di tinjau lebih dalam memiliki makna bahwa anak usia dini memiliki kesempatan dan peluang emas untuk belajar sehingga di katakan sebagai golden age, selain itu pada anak usia dini, mereka memiliki kemampuan yang sangat luar biasa dalam menyerap ilmu pengetahuan yang di ajarkan oleh para pendidiknya sehingga wajar apabila generasi muda dikatakan sebagai generasi penerus bangsa.

Membahas lebih mendalam tentang kondisi generasi muda penerus bangsa, tidaklah terlepas dari kenyataan atas sebuah kondisi pilu, dimana masih banyak di jumpai generasi muda yang seharusnya memperoleh pendampingan dan bimbingan orang tua di masa tumbuh kembangnya, namun mereka harus menghadapi sebuah kenyataan pahit bahwa mereka tidaklah memiliki orang tua dan harus hidup dan tinggal bersama rekan lainnya yang juga memiliki kesamaan nasib dalam sebuah asrama atau yayasan panti asuhan.

Yayasan panti asuhan "Khazanah Kebajikan" adalah sebuah lembaga berbentuk yayasan yang didirikan berdasarkan asas keagamaan dan bergerak di bidang sosial dan beralamatkan di Jl. Talas 1, Pd. Cabe Ilir, Kec. Pamulang, Kota Tangerang Selatan, Banten 15419. Tujuan dari dibentuk dan di dirikannya Yayasan panti asuhan Khazanah Kebajikan yaitu membantu para anak asuh yang notabenenya merupakan anak yatim dan piatu untuk dapat mengenyam ilmu dan pendidikan serta kehidupan yang layak untuk bekal hidupnya di masa mendatang.

Untuk membekali pengetahuan dan keterampilan yang di butuhkan para anak asuh yang berada di bawah asuhan yayasan yatim dan piatu khazanah kebajikan di butuhkan sebuah kegiatan berupa pelatihan-pelatihan yang mampu meningkatkan mutu dan kompetensi anak asuh.

Salah satu jenis pelatihan yang dibuthkan oleh anak asuh yang berada di bawah asuhan yayasan yatim dan piatu khazanah kebajikan adalah pelatihan desain grafis dengan menggunakan aplikasi desain grafis menggunakan aplikasi corel draw.

Corel Draw merupakan program pengolah desain grafis yang familier dan paling diminati di 


\section{JURNAL ABDIMAS

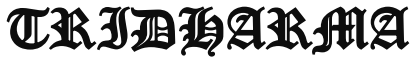

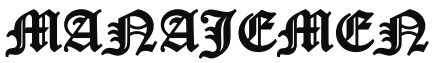

P-ISSN 2615-6849, E-ISSN 2716-070X

Jurnal ABDIMAS Vol.3,No.1,Desember 2021,Hal(92-99)

@ Prodi Manajemen Fakultas Ekonomi Universitas Pamulang

Email: abdimasjurnal.unpam@ gmail.com Telp: (021) 741-2566 kalangan desain grafis. Program ini dapat digunakan dengan mudah karena terdapat tooltool maupun efek yang menghasilkan berbagai bentuk desain yang inovatif dan ekspresif dengan dilengkapi komposisi warna yang bagus, serta adanya tool untuk membuat objek yang unik dan kreatif. Desain grafis atau rancang grafis adalah proses komunikasi menggunakan elemen visual, seperti tulisan, bentuk, dan gambar yang dimaksudkan untuk menciptakan persepsi akan suatu pesan yang disampaikan.Desain grafis pada awalnya diterapkan untuk media-media statis, seperti buku, majalah, dan brosur. Sebagai tambahan, sejalan dengan perkembangan zaman, desain grafis juga diterapkan dalam media elektronik, yang sering kali disebut sebagai desain interaktif atau desain multimedia.

Namun, di masa pandemi seperti sekarang ini memunculkan berbagai kendala dan masalah bagi yayasan Khazanah Kebajikan dimana biasanya untuk membiayai kebutuhan operasional, yayasan banyak memperoleh donasi dari para donatur, namun saat ini banyak donatur biasanya memberikan donasi tiap bulannya terhenti akibat berbagai kendala. Hal lain yang juga menjadi sorotan adalah masih terdapat beberapa anak asuh yang sudah lulus Sekolah Menengah Atas (SMA) yang belum mendapat pekerjaan akibat dampak pandemi covid-19 dan minimnya kompetensi dan keahlian yang dimiliki oleh anak asuh untuk mengembangkan ide-ide kreatif dan inovatif menjadi suatu produk yang dapat di terima dan di butuhkan masyrakat, sehingga mereka enggan mencoba untuk menjadi seorang enterpreunerships. Permasalahan lain yang juga kerap di hadapi oleh mitra adalah kurangnya sarana dan prasarana dalam mendukung kegiatan proses belajar dan mengajar khususnya pembelajaran terkait keterampilan dan kompetensi di bidang teknologi desain grafis, hal ini dapat terlihat dari terbatasnya jumlah pendidik yang memiliki pengetahuan dan kompetensi di bidang desain grafis dan fasilitas komputer yang mendukung kegiatan pembelajaran.

\section{RUMUSAN MASALAH}

Berdasarkan latar belakang masalah di atas, maka dapat dirumuskan masalah sebagai berikut:

1. Bagaimana cara menumbuh kembangkan jiwa enterpreunerships pada anak asuh yang berada di bawah naungan Yayasan Yatim dan Piatu "Khazanah Kebajikan"?

2. Bagaimana pemahaman anak asuh tentang yang berada di bawah naungan Yayasan Yatim dan Piatu "Khazanah Kebajikan" tentang kegiatan wirausaha?

3. Bagaimana pemahaman anak asuh tentang seni desain grafis dan aplikasi desain grafis?

4. Bagaimana metode yang paling efektif dalam memberikan pemahaman dan pelatihan desain grafis dengan menggunakan aplikasi desain grafis bagi para anak asuh yang berada di bawah naungan Yayasan Yatim dan Piatu "Khazanah Kebajikan"?

\section{TUJUAN PELAKSANAAN}

1. Mengedukasi dan menumbuh kembangkan jiwa enterpreneurships di usia dini pada anak asuh yang berada di bawah naungan yayasan Yatim dan Piatu

2. Empowerment cita-cita dan semangat pada anak asuh yang berada di bawah naungan yayasan Yatim dan Piatu "Khazanah Kebajikan" untuk berkreasi, mengarahkan kegiatan mereka agar bermanfaat dimasa yang akan datang sehingga dapat meningkatkan kemandirian mereka dalam menghadapi persaingan secara global yang kian kompetitif.

3. Memperkenalkan dan memberikan pelatihan pada anak asuh yang berada di bawah naungan yayasan Yatim dan Piatu 


\section{JURNAL ABDIMAS

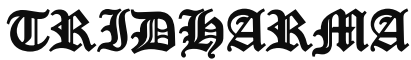

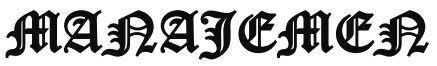

P-ISSN 2615-6849, E-ISSN 2716-070X

Jurnal ABDIMAS Vol.3,No.1,Desember 2021,Hal(92-99)

@ Prodi Manajemen Fakultas Ekonomi Universitas Pamulang

Email: abdimasjurnal.unpam@gmail.com Telp: (021) 741-2566
"Khazanah Kebajikan" dalam menggunakan dan memanfaatkan salah satu teknologi aplikasi desain grafis yaitu Aplikasi Coreldraw sebagai dasar dari penumbuhan jiwa enterpreunerships.

\section{TINJAUAN PUSTAKA}

\subsection{Pelatihan}

\section{Pengertian Pelatihan}

Berdasarkan terjemahan dari Kamus Besar Bahasa Indonesia (KBBI), kata pelatihan berasal dari kata dasar Latin yang berarti belajar dan membiasakan diri agar mampu atau dapat melakukan sesuatu. Selanjutnya, banyak pakar yang berpendapat mengenai pengertian dari pelatihan diantaranya yaitu, Menurut Desler (2017:323) "pelatihan adalah proses mengajarkan karyawan baru atau yang ada sekarang, keterampilan dasar yang mereka butuhkan untuk menjalankan pekerjaan mereka".

Selain pendapat yang di kemukakan oleh Desler, Widodo (2015:82), juga mengungkapkan pengertian tentang "pelatihan merupakan serangkaian aktivitas individu dalam meningkatkan keahlian dan pengetahuan secara sistematis sehingga mampu memiliki kinerja yang profesional di bidangnya".

Senada dengan pendapat yang di kemukakan oleh widodo, Gomes (2017:197) mendefinisikan "pelatihan adalah setiap usaha untuk memperbaiki prestasi kerja pada suatu pekerjaan tertentu yang sedang menjadi tanggung jawabnya".

Menurut Rachmawati (2008:110), "pelatihan merupakan wadah lingkungan bagi karyawan, di mana mereka memperoleh atau mempelajari sikap, kemampuan, keahlian, pengetahuan, dan perilaku spesifik yang berkaitan dengan pekerjaan".

Merujuk dari berbagai pendapat serta pemaparan yang telah di kemukakan oleh ahli terdahulu diatas dapat maknai bahwa pelatihan adalah salah satu usaha dalam meningkatkan mutu sumber daya manusia dalam dunia usaha.

2. Tujuan Pelatihan

Tujuan pelatihan pada hakekatnya menyangkut halhal sebagai berikut:

a. Produktivitas Kerja

Dengan pelatihan, produktifitas kerja karyawan akan meningkat, kualitas dan kuantitas produksi akan semakin baik, karena technical skill, human skill dan manajerial skill yang semakin baik.

b. Efisiensi

Pelatihan bertujuan untuk meningkatkan efesiensi tenaga, waktu, dan bahan baku,

c. Kerusakan

Pelatihan karyawan bertujuan untuk mengurangi kerusakan barang, produksi dan mesin-mesin karena karyawan semakin ahli dan terampil dalam melaksanakan pekerjaannya.

d. Kecelakaan

Pelatihan bertujuan untuk mengurangi tingkat kecelakaan karyawan, sehingga jumlah biaya pengobatan yang dikeluarkan perusahaan berkurang.

e. Pelayanan

Pelatihan bertujuan untuk meningkatkan pelayanan yang lebih baik dari karyawan kepada pelanggan perusahaan, karena pemberian pelayanan yang baik merupakan daya penarik yang sangat penting bagi 


\section{JURNAL ABDIMAS

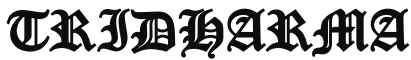

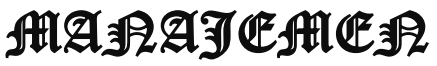

P-ISSN 2615-6849, E-ISSN 2716-070X

Jurnal ABDIMAS Vol.3,No.1,Desember 2021,Hal(92-99)

@Prodi Manajemen Fakultas Ekonomi Universitas Pamulang

Email: abdimasjurnal.unpam@ gmail.com Telp: (021) 741-2566 rekan-rekanan bersangkutan.

f. Moral

Dengan pelatihan, moral karyawan akan lebih baik karena keahlian dan keterampilannya sesuai dengan pekerjaannya sehingga mereka antusias untuk menyelesaikan pekerjaannya dengan lebih baik.

g. Karier

Dengan pelatihan, kesempatan untuk meningkatakan karier karyawan semakin besar, karena keahlian, keterampilan, dan prestasi kerjanya lebih baik. Promosi ilmiah biasanya didsarkan kepada keahlian dan prestasi kerja seseorang

3. Manfaat Pelatihan

Menurut Rivai dan Sagala (2011:217), adapun maanfaat pelatihan yang dibagikan menjadi tiga golongan, yaitu:

a. Manfaat untuk karyawan

1) Membantu karyawan dalam membuat keputusan dan pemecahan masalah yang lebih efektif.

2) Melalui pelatihan dan pengembangan, variabel pengenalan, pencapaian prestasi, pertumbuhan, tanggung jawab dan kemajuan dapat diinternalisasi dan dilaksanakan.

3) Membatu mendorong dan mencapai pengembangan diri dan rasa percaya diri.

4) Membantu karyawan mengatasi stress, tekanan, frustasi, dan konflik.

b. Manfaat untuk perusahaan

1) Memperbaiki sumber daya manusia

2) Membantu karyawan untuk mengetahui tujuan perusahaan.

3) Membantu menciptakan image perusahaan yang lebih baik.

4) Mendukung otentitas, keterbukaan dan kepercayaan

5) Meningkatkan hubungan antara atasan dan bawahan

\section{6) Membantu pengembangan perusahaan}

4. Jenis-Jenis Pelatihan

Setiap pendidikan dan pelatihan yang akan diadakan harus selalu memperhatikan sejauh mana pola pendidikan dan pelatihan yang diselenggarkan dapat menjamin proses belajar yang efektif. Menurut Widodo (2015:86), jenis-jenis pelatihan yang biasa dilakukan dalam organisasi antara lain:

a. Pelatihan dalam kerja (on the job training)

b. Magang (apprenticeship)

c. Pelatihan di luar kerja (of-thejob training)

d. Pelatihan di tempat mirip sesungguhnya (vestibule training)

e. Simulasi kerja (job simulation)

\subsection{Desain Grafis}

1. Pengertian Desain Grafis

$\begin{array}{lr}\text { Pengertian } & \text { desain } \\ \text { merupakan } & \text { sebuah } \\ \text { rancangan, rencana atau }\end{array}$
sebuah gagasan. Menurut Kamus Besar Bahasa Indonesia (KBBI) menyebutkan bahwa desain adalah 1. kerangka bentuk; rancangan, 2. motif pola; corak.

Selanjutnya menurut pendapat yang di kemukakan oleh Beta (2008:10) "Desain merupakan suatu proses kreatif dalam memecahkan suatu permasalahan dalam hal yang menyangkut perancangan suatu objek yang bersifat fungsional atau estetis. Yang pada prinsipnya melihat aspek teknis, fungsi, material, tanpa melepaskan 


\section{JURNAL ABDIMAS

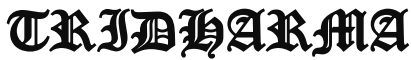

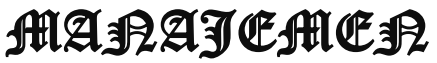

P-ISSN 2615-6849, E-ISSN 2716-070X

Jurnal ABDIMAS Vol.3,No.1,Desember 2021,Hal(92-99)

@ Prodi Manajemen Fakultas Ekonomi Universitas Pamulang

Email: abdimasjurnal.unpam@gmail.com Telp: (021) 741-2566 unsur warna, garis, tekstur, keseimbangan komposisi, dan bentuk"

Hendi Hendratman (2010:3), mendefinisikan "Desain grafis dapat diartikan sebagai prosese pemikiran yang diwujudkan dalam gambar Setiap perusahaan perusahaan atau individu memerlukan pekerjaan seorang desain grafis, sebagai web design, sign system logo, dan lain-lain"

2. Elemen-Elemen Desain Grafis

Menurut Andy dalam bukunya (2005: 46), elemen-elemen dasar tersebut adalah sebagai berikut:

a. Warna

Warna merupakan elemen yang tak terpisahkan atau yang terpenting dalam sebuah desain grafis

b. Garis

Garis merupakan kombinasi dari titik-titik yang saling berhubungan untuk membentuk sebuah objek.

c. Titik

Titik merupakan bagian terkecil dari garis karena pada dasarnya suatu garis dibentuk oleh adanya hubungan titik-titik yang sangat dekat

d. Bentuk

Bentuk merupakan suatu wujud yang menempati ruang dan biasanya memiliki dimensi dua atau tiga, yang biasanya disebut 2 dimensi dan 3 dimensi

e. Layout

Layout adalah usaha untuk menyusun, menata unsur-unsur grafis (teks dan gambar) menjadi media komunikasi yang efektif.

3. Aplikasi Desain Grafis

\section{a. Coreldraw}

Kegunaan corel draw itu sebenarnya sangat banyak, bahkan bisa dikatakan tidak terbatas. Namun oleh para penggunanya program ini sering dimanfaatkan untuk melakukan pekerjaan antara lain, yaitu:

1). Menciptakan desain symbol atau logo Ini adalah kegunaan corel draw yang sering dimanfaatkan penguunannya, terutama gambar logo dua dimensi.

2). Membuat desain undangan, brosur, dan lainlain Kegunaan corel draw yang lain adalah untuk menciptakan desain undangan (pernikahan, khitanan, dll) atau brosur dan media publikasi lainnya.

3). Membuat cover buku Para pembuat cover buku atau majalah saat ini juga sering memanfaatkan kegunaan corel draw untuk kemudahan desain tugas-tugas mereka.

4). Membuat gambar ilustrasi Para pembuat gambar ilustrasi juga tidak mau kalah dalam memanfaatkan corel draw. Karena gambar yang dihasilkan bisa lebih berkualitas. Terutama ketika melakukan perhitungan tentang besaran derajat lengkung, garis atau sudut. Demikian pula untuk embuat garis atau bidang yang datar. Ukuran yang diperoleh dijamin sangat tepat dan akurat.

b. Photoshop

Photoshop merupakan salah satu software yang paling banyak dipakai dalam dunia publikasi, fotografi, video dan juga bidang berorientasi visual lainnya, software ini punya banyak potensi untuk membantu proses desain dan visualisasi berbagai ragam pekerjaan

HASIL DAN PEMBAHASAN

4.1 Hasil

Kegiatan Pengabdian

Kepada Masyarakat (PKM) yang dilakukan oleh dosen Prodi 


\section{JURNAL ABDIMAS

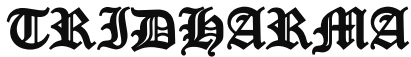

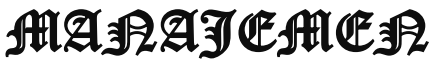

P-ISSN 2615-6849, E-ISSN 2716-070X

Jurnal ABDIMAS Vol.3,No.1,Desember 2021,Hal(92-99)

@ Prodi Manajemen Fakultas Ekonomi Universitas Pamulang

Email: abdimasjurnal.unpam@ gmail.com Telp: (021) 741-2566
Manajemen S1 Universitas Pamulang ini bertujuan untuk meningkatkan potensi dan keterampilan anak asuh pada panti asuhan "Khazanah Kebajikan" dengan cara memberikan pelatihan desain grafis dan pembekalan akan pemahaman tentang jiwa enterpreneurships.

Kegiatan Pengabdian Kepada Masyarakat yang telah dilaksanakan tersebut di bagi menjadi tiga tahapan yaitu sebagai berikut :

\section{Tahap Pertama :}

Pada tahapan pertama ini di lakukan kegiatan sosialisasi dan edukasi pada para peserta pelatihan tentang penting memiliki jiwa enterpreunership dalam diri setiap peserta pelatihan. Pemaparan materi tentang enterperneurship di bawakan oleh Nurul Ilham, S.E., M.M.

\section{Tahap Kedua:}

Pada tahapan kedua kegiatan pengabdian kepada masyrakat ini dilakukan kegiatan pelatihan menggunakan aplikasi desain grafis, dimana aplikasi yang di pergunakan di dalam pelatihan ini adalah aplikasi coreldraw dan aplikasi adobephotoshop. Para peserta pelatihan di latih untuk membuat desain banner, cover buku dan desain logo menggunakan kedua aplikasi desain grafis tersebut. Materi pelatihan pada pertemuan kedua ini di bawakan oleh Bapak Anggada Bayu Seta, S.E., M.M.

\section{Tahap Ketiga :}

Pada tahapan ketiga kegiatan pengabdian kepada masyrakat ini dilakukan sebuah evaluasi terhadap hasil praktikum desain yang telah di buat oleh para peserta pada hari sebelumnya, dan di lanjutkan dengan diskusi terkait peluang usaha bagi seorang enterpreneur muda. Materi evaluasi dan diskusi pada pertemuan ke tiga ini di bawakan oleh Bapak Anggada Bayu Seta, S.E.,M.M.

\subsection{Pembahasan}

Kegiatan Pengabdian Kepada Masyarakat (PKM) yang dilakukan oleh dosen Prodi Manajemen S1 Universitas Pamulang pada panti asuhan "Khazanah Kebajikan" dikatakan dapat memberikan kontribusi terhadap para peserta pelatihan, hal ini dapat di lihat antusias para peserta mengikuti kegiatan pelatihan dimana terjadi sebuah transfer knowledge dan peningkatan kompetensi para peserta pelatihan, hal ini dapat di lihat dari keberhasilan para peserta menggunakan aplikasi desain baik disertai dengan hasil desain yang menarik dan kreatif.

\section{KESIMPULAN DAN SARAN \\ 5.1 Kesimpulan}

Berdasarkan hasil evaluasi terhadap materi dan hasil yang berhasil dicapai oleh para peserta pelatihan, selama pelaksanaan kegiatan Pengabdian Kepada Masyarakat ini, dapat kami simpulkan bahwa kegiatan ini telah mampu memberikan manfaat yang sangat besar dan tepat sasaran bagi khalayak anak-anak panti asuhan yang menjadi khalayak sasaran dalam kegiatan ini.

\subsection{Saran}

Sesuai dengan hasil evaluasi yang telah dilakukan, kami menyarankan hendaknya program-program pelatihan seperti ini bisa dilaksanakan secara rutin, mengingat tingkat kebutuhan dan peminat akan seni desain grafis yang sangat tinggi dan dapat menjadi sebuah solusi dalam menciptakan jiwa seorang enterpreneur serta peluang usaha bagi para pelaku dan masyrakat sekitar.

\section{DAFTAR PUSTAKA}

Coy, Or dan Katamsi, Yanwar, 2008. Teknik Cetak Cepat di Aneka 


\section{JURNAL ABDIMAS

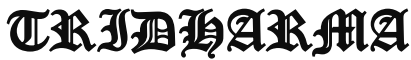



P-ISSN 2615-6849, E-ISSN 2716-070X

Jurnal ABDIMAS Vol.3,No.1,Desember 2021,Hal(92-99)

@Prodi Manajemen Fakultas Ekonomi Universitas Pamulang

Email: abdimasjurnal.unpam@gmail.com Telp: (021) 741-2566
Media, Jakarta. Kawan Pustaka Enterprise,

Jubilee. 2009, Kiat Praktik Membuka Usaha Bermodalkan Photoshop, Jakarta, Elex Media Komputindo

Hidayatullah, Taufik, 2008, Lengkap dan Cepat Membuat Desain dengan CorelDraw MX4, Yogyakarta, Mediakom Komputer,

Wahana, 2010, Panduan Praktis Desain Grafis Profesional dengan Adobe Photoshop CS4, Yogyakarta, Andi Publisher

Sulthoni, Yahya, 2013, Strategi Pemben tukan Karakter Anak di Panti Asuhan Muhammadiyah Wiyung Surabaya, Jurnal Kajian Moral dan KewarganegaraanNomor 1 Volume 1 Tahun 2013

Budi Santoso, 2013, Skema dan Mekanisme Pelatihan Panduan Penyelenggaraan Pelatihan, Penerbit Yayasan Terumbu Karang Indonesia (TERANGI), Jakarta.

Juliansyah Noor, 2011, Motodologi Penelitian, Perpustakaan nasional : katalog Dalam Terbitan (KDT), Penerbit Kencana, Jakarta.

Pasaribu, V. L. D., Agrasadya, A., Shabrina, N., \& Krisnaldy, K. (2020). Menjadi Enterpreneur Muda Yang Memiliki Jiwa Leadership Untuk Menghadapi Masa Depan. Abdi Laksana: Jurnal Pengabdian Kepada Masyarakat, 1(1).

Pasaribu, V. L. D., Susanti, F., \& Hartuti, E. T. K. (2019). Memotivasi Siswa dan Siswi SMK Letris Indonesia di Dalam Menentukan Pilihan Untuk Melanjutkan Pendidikan Atau Bekerja Setelah Lulus Sekolah. Jurnal Pengabdian Dharma Laksana, 1(2), 161172.

Pasaribu, V. L. D., Sulaiman, S., Sutiman, S., Thaharudin, T., \& Purnomo, B. Y. (2020). Pengenalan Letak Posyandu Terdekat Dikelurahan Pisangan Dengan Manajemen Pemasaran Revolusi 4.0 Untuk Pasaribu, V. L. D., Septiani, F., Rahayu, S., Meningkatkan Pengetahuan Masyarakat Letak Dan Fungsi Posyandu Terdekat Pada
Kelurahan Pisangan. Dedikasi Pkm, 1(1), 105-110.

Pasaribu, V. L. D., Oktrima, B., Prabowo, B., Arianto, N., \& Haryoko, U. B. (2020). Progam Pendampingan Dan Penyelenggaraan Pendidikan Anak Pada Usia Dini Terhadap Prestasi Belajar Dilingkungan Rt 020 Rw 009. Kel Giri Peni. Kec Wates. Yogyakarta. Jurnal Lokabmas Kreatif, 1(1), 71-75.

Pasaribu, V. L. D., Jannah, M., Fazar, M., Putra, S. P., Monalisa, M., \& Sofa, M. (2021). MENINGKATKAN PRODUKTIVITAS USAHA DIMASA PANDEMI PADA IBU PKK RT 004/003 KELURAHAN SAWAH BARU CIPUTAT, TANGERANG SELATAN. Abdi Laksana: Jurnal Pengabdian Kepada Masyarakat,2(2), 295301.

Pasaribu, V. L. D., Yuniati, H. L., Pranata, R., Sembayu, R., Purba, S. M., \& Nurbayani, T. T. A. (2021). MANAJEMEN KEUANGAN UNTUK MENGHADAPI DAN BERTAHAN DI ERA COVID 19. Jurnal Abdimas Tri Dharma Manajemen, 2(2), 12-18.

Pasaribu, V. L. D., Dwiyatni, A., Sabina, C., Ridwan, M., Gunawan, D. D., \& Noviani, B. C. (2021). EVALUASI PENERAPAN 3M DIMASA PANDEMIC COVID 19. Jurnal Abdimas Tri Dharma Manajemen, 2(2), 54-60.

Pasaribu, V. L. D., Syafei, A. N., Farhan, A., Aufaizah, A., Irani, C., \& Firtiayani, S. R. (2021). PENGARUH DISPLIN PROTOKOL KESEHATAN TERHADAP PENCEGAHAN PENULARAN VIRUS COVID19. Jurnal Abdimas Tri Dharma Manajemen, 2(2), 91-98. Lismiatun, L., Arief, M., Juanda, A., ... \& Rahim, R. (2021). 


\section{JURNAL ABDIMAS

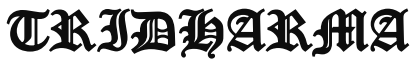

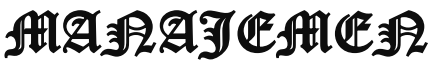

P-ISSN 2615-6849, E-ISSN 2716-070X

Jurnal ABDIMAS Vol.3,No.1,Desember 2021,Hal(92-99)

@ Prodi Manajemen Fakultas Ekonomi Universitas Pamulang

Email: abdimasjurnal.unpam@gmail.com Telp: (021) 741-2566
Forecast Analysis of Gross Regional Domestic Product based on the Linear Regression Algorithm Technique.

Priadi, A., Pasaribu, V. L. D., Virby, S., Sairin, S., \& Wardani, W. G. (2020). Penguatan Ekonomi Kreatif Berbasis Sumber Daya Desa Dikelurahan Rempoa. Abdi Laksana: Jurnal Pengabdian Kepada Masyarakat, 1(3), 35635

Pasaribu, V. L. D., Priadi, A., Anismadiyah, V., Rahayu, S., \& Maduningtias, L. (2021). PENYULUHAN KREATIF DAN INOVATIF MENINGKATKAN MUTU PRODUKSI UMKM DI DESA BELEGA KABUPATEN GIANYAR. Pro Bono Jurnal Pengabdian Kepada Masyarakat, 1(02).

Pasaribu, V. L. D. (2021). PELATIHAN BERBASIS ONLINE DI ERA COVID-19. Jurnal Abdimas Tri Dharma Manajemen, 2(3), 2632.

Pasaribu, V. L. D., \& Setyowati, R. (2021). ADAPTASI KEHIDUPAN NEW NORMAL PADA MASA PANDEMI COVID-19 DIYAYASAN PONDOK PESANTREN DAN PANTI ASUHAN NURUL IKHSAN KECAMATAN SETU, KOTA TANGERANG SELATAN. Jurnal Lokabmas Kreatif: Loyalitas Kreatifitas Abdi Masyarakat Kreatif, 2(2), 82-88.

Suparno Sastra M, 2016, Kreasi Desain Grafis Inovatif dengan Corel Draw, PT Elex Media Komputindo, Jakarta

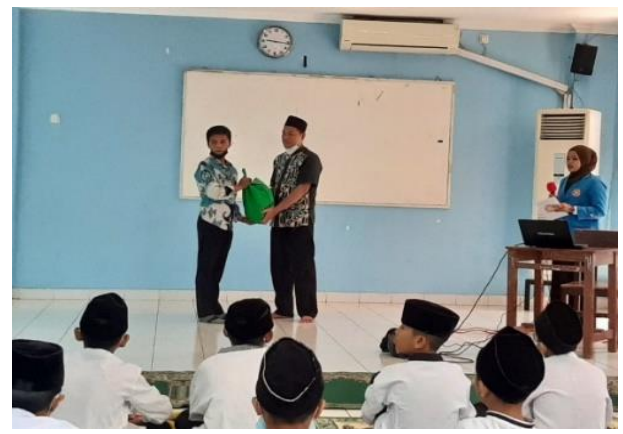



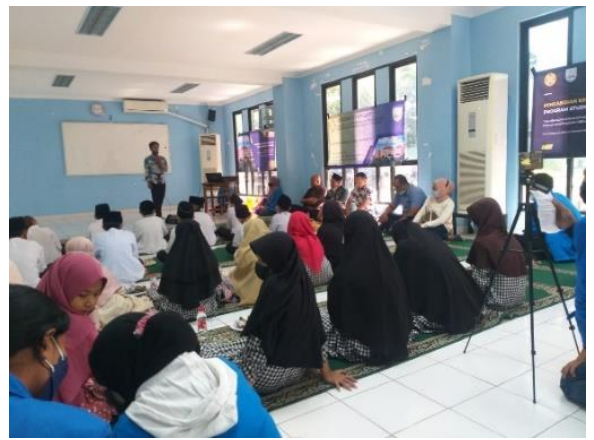

